\title{
The Mediating Role of Intellectual Capital in Corporate Governance and the Corporate Performance Relationship
}

\author{
Sohail Saeed \\ Siti Zaleha Abdul Rasid \\ Rohaida Basiruddin \\ International Business School (IBS), Universiti Teknologi Malaysia, Kuala Lumpur, Malaysia \\ ssohail2@live.utm.my
}

Doi:10.5901/mjss.2015.v6n5p209

\begin{abstract}
Corporate governance significantly effects corporate performance and this relationship is established through number of studies theoretically and empirically conducted in this field. Also, there are studies which show the relationship between corporate governance and intellectual capital performance. Furthermore, intellectual capital performance positively effects corporate performance as shown in the previous studies. These relationships trigger this study to explore the role of intellectual capital as a mediator between corporate governance and corporate performance relationship. This study focuses on the idea that governance measures, board of directors in this study, can contribute to the intellectual capital efficiency of the companies which in turn results in higher corporate performance. A single structural model of corporate governance, intellectual capital and corporate performance is conceptualized. In the model, board of directors, variables are taken as governance measures, Value Added Intellectual Coefficient (VAICTM) as intellectual capital performance measure and traditional financial measures as corporate performance measures. It is intellectual capital resources which act as mechanism through which the corporate governance is able to influence the corporate performance. Intellectual capital is taken as mediator to confirm that IC properly mediates the CG and performance relationship conceptually. This study will be beneficial for the research community to combine different areas of study under one model. This study will suggest the management and other regulatory bodies to understand the importance of intellectual capital along with governance and performance.
\end{abstract}

Keywords: corporate governance (CG), intellectual capital (IC), corporate performance (CP),

\section{Introduction}

Corporate governance is "a system by which companies are directed and controlled" (Cadbury Report 1992: 15). This definition involves all the rules and regulations needed to run and monitors the functions of the companies properly. Shleifer and Vishny (1997: 737) define corporate governance as "a process in which suppliers of finance to corporations assure themselves of getting return on their investment". This means that companies should generate profit and return this profit back to the shareholders and creditors who supplied finance for the activities of business. These definitions support the agency theory perspective which demands that board of directors should act as agents of shareholders and monitor the activities of management to avoid any risk of managerial embezzlement. Alternatively, CG is also defined as "a system of checks and balances, both internal and external to companies, which ensures that companies discharge their accountability to all their stakeholders and act in a socially responsible way" (Solomon's 2007: 14). This stakeholder's theory emphasizes that shareholders are not the only stakeholders of the company, but other groups like customers, suppliers, governments and society are also the stakeholders of the company. In resource dependency theory, CG is viewed like a mechanism which develops outside links with all interested groups in the company to receive important resources for the company (Voordeckers et al., 2007). Donaldson (1990), in the perspective of stewardship theory, defines CG as a system in which managers are loyal and trustworthy persons and can be relied for the maximization of returns without the need and support of outside directors.

Although, there are different perspectives and theories of CG, but corporate governance is a broad area which covers corporate law, financial reporting, auditing and code of corporate governance, and it is believed that good CG practices are required to guarantee business success, development, trust of investors and higher market return.

In this study, CG is viewed as characteristics of the board of directors. Corporate boards make important, strategic 
and policy decisions regarding investment, finance, product development, market expansion and board governance, etc. In the previous literature, the relationship between CG measures and corporate performance has been thoroughly discussed (e.g., Bebchuk et al., 2011; Chhaochharia and Grinstein, 2007; Cremers and Nair, 2005; Ho, 2011). However, the results are mixed and inconclusive. Some studies found that CG positively effects the corporate performance (Bai et al., 2004; Belkhir 2009; Khan and Awan 2012; Larmou and Vafeas 2009) and there are studies which did not ffind any relationship between them (Abdullah \& Page, 2009; Shukeri et al., 2012; Topak 2011).

On the other side, there is no proper definition of IC as this concept is emerged in the eighties of the 20th century. Dr. Karl-Erik Sveiby is among the "founding fathers" of Knowledge Management, published his first book in Swedish language and named, "Kunskapsföretaget" means "Knowledge Company" in which he described the ways to manage the growing knowledge companies which do not have production processes but the knowledge and creative skills of employees. In 1991, Stewart wrote an article in fortune magazine which was considered as the first article on IC (Sullivan, 2000). According to Mention (2012) "IC is a set of internal and external resources (human, process, IT-based or enabled) that organizations mobilize and articulate, through activities, with other resources (financial and tangible) in order to further generate resources, which can be of tangible, intangible or financial nature, in their pursuit of competitive advantage". Human capital is defined as knowledge, skills, and abilities of employees contributed in the work. Structural capital means innovations, organizational processes, culture, intellectual property, databases, software, hardware, etc. Relational capital involves licenses, franchises, interactions with stakeholders and interested parties in the business to get favour for the proper functioning of the organizations (Mention 2012). In this study, IC performance is taken as intellectual capital efficiency which is measured through human capital, structural capital and capital employed efficiencies (Pulic 2004). A number of studies in recent years can be found in literature which has shown significant relationship bettween intellectual capital and corporate performance (Chan 2009; Chen et al., 2005; Komnenic \& Pokrajc ic 2012; Mehralian et al., 2012; Pal \& Soriya 2012; Ze'ghal \& Maaloul 2010).

In the last, firm performance can be measured through quantitative and qualitative measures. Quantitative measures include increase in sales, profit, total assets, market value or book value of assets or equity, etc. (Goh, 2005). Qualitative measures include quality of workers life, safety and security measures, environmental issues, etc. A firm is viewed like an entity that takes funds from stockholders, creditors, and dealers to generate products for its customers (Donaldson and Preston, 1995). According to this view, corporate performance means financial returns to the owners of the firm from the exploitation of tangible assets (Donaldson \& Preston, 1995; Riahi-Belkaoui, 2003). However, the resource based view recognizes firms to receive both, the tangible and intangible assets (Skinner, 2008). Promoters of resource-based theory of corporate governance argue that corporate performance is the function of active utilization of tangible and intangible assets of the organization (Zahn et al., 2004). This study views mostly used financial measures to determine the corporate performance like return on assets, return on equity and asset turnover ratio as they are easily found in the audited annual reports of the companies.

Board of directors' characteristics and corporate performance link has been discussed in the literature and codes of corporate governance have been introduced in different countries based on the discussion in the literature. It is agreed that corporate governance practices are linked with increased corporate performance. But the relationship is not so simple and straightforward, especially during the financial crisis in the world (2008-2012), many companies were bankrupted In USA despite the corporate governance was effective and intact in those companies e.g. Lehman Brothers Holdings Inc., Washington Mutual, GM, Chrysler, Thornburg Mortgage, and hundreds other). This may mean that board of directors of those companies failed to serve the purpose for which they were hired (Gupta et al., 2013). There is a need of time to study and understand this known relationship between CG and corporate performance more thoroughly and rigorously. This can be done by adding IC as mediator in this relationship.

Board of directors is responsible to establish effective strategies to acquire and utilize human and structural resources at their best. These resources help to improve productions capacities and processes and result in new patent development activities. Nicholson et al., (2004) argued that board of directors' relational capital can be judged through relationship with large corporate customers and suppliers. The goal of business is to increase the owner's returns, i.e. shareholders. Owners are concerned with the intellectual capital of the firm if it is helpful to yield higher financial returns.

Henceforth, this paper uses intellectual capital as a mediator which takes its input from the corporate governance measures and yields its output in the form of corporate performance. This is the first study to focus three important business areas like CG, IC and performance in mediating relationship. 


\section{Literature Review}

\subsection{Corporate Governance and Corporate Performance}

Number of studies has discussed the relationship between corporate governance and corporate performance but the results are non-conclusive. Different structures of governance resulted in varying level of performance (Adams et al., 2010; Belkhir 2009; Khan \& Awan 2012; Larmou \& Vafeas 2009; Topak 2011). In order to develop a structural model, this study uses board of directors' characteristics as CG measures which may have impact on both IC and corporate performance.

Non-executive directors: The outside non-executive directors with diversifiable abilities, extensive knowledge and vast working experience act as assets for the company to add value to the firm rather than just auditors (Mueller et al., 2008). Prior studies showed the mixed result of outside directors and the firm performance. Khan and Awan (2012) showed a positive relationship between non-executive directors on board and return on assets and return on equity. Shukeri et al., (2012) found a negative link between non-executive directors on board and corporate performance after analysis of three hundred companies of Malaysia stock exchange.

Female directors on board: Women' directors add distinctive skills, knowledge, and capability to their boards. Women directors are characterized by; innovative, possessing a unique and strategic decision making ability (Daily et al., 1999; Zelechowski \& Bilimoria, 2004; Dezs and Ross, 2012), mentors, role models for female employees (Bilimoria, 2006), the recruiter and retainer of female employees (Bilimoria, 2000), concerned for community (Graves and Powell, 1988), Philanthropic (Williams, 2003), open and effective communicator and explicit implementer of corporate strategy (Brown et al., 2002). However, empirical studies showed mixed relationship between women directors and the company's performance. Haslam and Ryan (2008) investigated female appointments on BOD and did not find any relationship between females' presence on boards and return on assets and return on equity. Adams and Ferreira (2009) studied US firms and concluded that the average effect of female presence on company performance is negative. However, Abdullah et al., (2012) have done an empirical analysis of 841 publicly-listed firms in Malaysia and result reveals a significant positive relationship of females' role in board and return on assets.

Expertise of directors on board: Knowledge, skills and expertise of individual director also contribute to firm performance as shown in the study of Dhaliwal et al., (2010) who showed a positive relation between financial expertise of audit committee directors and reporting performance. In addition, Kim et al., (2011), in their empirical study of more than 15000 firm-year observations for 6 years find a significant positive relationship between firm specific knowledge, i.e. experience with the operating performance (a measure of advising role). They also concluded that individual specific knowledge, i.e. financial expertise has negative impact on financial reporting (monitoring role) by the board. At the end, it is suggested that when the board of directors, possesses financial knowledge, experienced, and have a good educational background, they can understand and address issues relating to business affairs.

Role duality: There has been extensive debate in the literature on the dual role of CEO and chairperson of the board but it remains inconclusive. Some studies are in favour of duality and some are opponents to this role. Proponents stress that if the same person performs the two functions and run two offices at the same time, it will lead to understand the business activities more (Weir et al., 2002). Stewardship theory holds that executive directors act in the best interest of the firm and undue pressure of chairman on CEO decisions can be avoided. It may also accelerate decision making through saving time from unnecessary discussions. Opponents claim that if a single person occupies both the positions then it would result in agency problems. Bai et al., (2004) discussed that separate roles of CEO and chairman of board could result in higher financial performance. Gul et al., (2011) found a negative association between role duality and corporate performance of the textile sector of Karachi stock exchange (KSE).

Outside directorship of inside directors: Masulis and Mobs (2011) argue that those executive directors who have outside directorship in other boards of companies perform better in their companies and eventually the company performance increases. Directors from related industries also contribute their knowledge, broad exposure and experience in the company's board of directors and share positively in enhancing corporate performance (Dass et al., 2011). They also represent the relational capital of board of directors which can be utilized to bring valuable resources in the organization by combining networks of those directors' relations (Dalziel et al., 2011). Fama and Jensen (1983) claimed that those persons who are identified by the labour market as valuable and skillful are better able to get outside directorships. Further, the outside directorship enhances the chances for career development for the inside directors and they can perform independently in their parent firms without fear of CEO. Carcello et al., (2002) advocated that directors with more outside directorships tend to perform better as they are prone to more experience, diversified working environment and broad exposure. 
In this predicament of contradictory opinions and evidences from the literature in which some studies support the link between CG and performance, and others did not, this study suggests its first hypothesis as follows:

H1: CG measures significantly effect the corporate performance.

\subsection{Corporate Governance and Intellectual Capital}

CG and IC was discussed conceptually by Keenan and Aggestam in year 2001. According to them, IC exists in every organization irrespective of its recognition by the board and the duty of the corporate governors is to generate, develop and leverage IC stored in people, processes and organizational structure (Keenan \& Aggestam, 2001). A second study performed by Williams (2000), attempts to empirically verify the link between CG measures and IC performance by taking data of 84 companies listed in South Africa stock exchange. He found a positive link between gender, race and duality of chairman role with the IC performance. The third study was done by Ho and Williams (2003), who covered link between board structure and IC efficiency in a sample of South African, Sweden and UK listed companies, but they could not find any relationship among independent directors, board size, role duality, director ownership and VAICTM. A fourth study conducted by Swartz and Firer (2005) concludes that racial diversity is positively related to IC performance in a sample of one hundred and seventeen public listed companies in South Africa.

Zamani et al., (2012) studied the association among three board characteristics, i.e. size, independent directors and role duality, and intellectual capital efficiency by using VAICTM in Tehran Security Exchange. They concluded that there is a positive link among them. In the same way, in Malaysia, Abidin et al., (2009) conducted a study and concluded that there is positive link between large board size and IC performance. They also showed positive link between number of non-executive directors and IC. In view of the earlier research comes about, the following hypothesis of this study is:

H3: CG measures significantly effect IC performance.

\subsection{Literature on IC and Corporate Performance}

In 1995, Skandia issued the first report on IC for internal decision making. Brookings (1996 p.12) gave a broad meaning of intellectual capital expressing it as "the combined intangible assets which enable the company to function." Stewart (1997, p.67), in the meantime, termed intellectual capital as "packaged useful knowledge." These definitions gave an initial understanding of the concept IC but failed to provide specific direction to identification of its specific components. Leif Edvinson, director for Skandia, declared that IC comprised of human and structural capital (Edvinson \& Malone, 1997). However, this classification was extended by Skyrme (1998) and customer capital was included as a third component of IC. The Organization for Economic Co-operation and Development (OECD), (1999 p.158) described IC as the "economic value of two categories of intangible assets of a company namely organizational capital and human capital".

Some researchers define IC in terms of knowledge and value creation for the companies. Dzinkowski $(2000$, p.32) regarded IC as "the total inventor of capital or knowledge-based resources owned by an organization". Bontis, (2004) explained IC as a stock of knowledge possessed by humans and not-human warehouses at a particular point of time. Phusavat and Kanchana (2007) advocated that any knowledgeable information originating from imagination and creativity of human and structural resources, can be named IC, if it is able to stock and adapt knowledge for value creation. The Value Added Intellectual Coefficient (VAICTM) is a commonly utilized model for measuring intellectual capital. In almost every empirical study (exception of survey studies) carried out to figure out a connection between IC and corporate performance, this technique is commonly used. It is proposed by Maditinos et al., (2011) that in developing countries where accounting standards are not properly met and financial structures are weak, this is the best techniques to be used. To use IC for this study, the following three efficiencies of IC are used.

Human capital efficiency (HCE): Human capital is composed of human skills and competencies and used to create the operational efficiency and value for the organization. Human capital is the ability of employees to contribute in the value addition and is measured through employees cost incurred to produce value (Pulic, 2004). Becker et al., (2001) found that expenditures on employee competences result in higher corporate performance..

Structural capital efficiency (SCE): SC is considered as an important tool in an organization. If the organization is weak in its SC, the best capabilities of employees may not create value for organization. Structural capital in terms of supportive culture, intellectual property, values, etc. offers helpful environment to its employees and hence the profit increases and cost decreases (Tan et al., 2007).

Capital employed efficiency (CEE): Capital employed efficiency means the contribution of financial and physical assets to generate value creation for the company. It means that intellectual capital resources cannot generate value 
without financial and physical resources (Pulic 2004). It also means that better utilization of financial and physical assets is likely to the well-organized human and structural capital (Makki \& Lodhi, 2009). VAICTM is overall intellectual efficiency at corporate level and is sum of all three efficiencies, i.e. HCE+SCE+CEE.

Various studies have attempted to examine the relations between intellectual capital and performance. RiahiBelkaoui (2003), used data of US multinational firms, found a positive relationship between IC and future performance. Following resource-based theory, Chen et al., (2005), recommended that IC adds to the corporate performance when they studied companies from Taiwan during the period 1992-2002.

Tan et al., (2007) showed a positive relation of IC with current and future corporate performance by using 150 firms in Singapore in 2007. Chan (2009) discovered the effects of IC efficiency on traditional measures of firm performance after collecting data of all companies from Hong Kong Stock Exchange for the years 2001 to 2005. Ze'ghal and Maaloul (2010) found a significant positive relationship between IC and corporate performance in terms of corporate measures when he examined 300 UK listed companies. According to Rahman, (2012) the higher IC efficiency leads to higher financial performance of firms. He empirically investigated the role of IC in financial performance of 100 UK companies from three industries, listed in London stock exchange for year 2009 by using the VAIC ${ }^{\text {TM }}$ model of IC. Morariu (2014) demonstrated a significant negative association between the VAICTM and market to book value and insignificant link between VAICTM and ROE. On the premise of mix results of former studies, this study proposes the following hypothesis.

2: IC performance significantly effects corporate performance.

\subsection{Mediation of Intellectual Capital}

Mediation refers to a series of causal relationships by which independent variable (IV) applies its effect on dependent variable (DV) through influencing dominant third variable (Hayes, 2013). Mediation analysis helps to understand an established relationship by realizing how one variable effects the other variable. Baron and Kenny (1986) explained four steps of the mediation process. The relevancy of each step to show methodological justification of IC as mediator with this study is given below.

i) The link between independent and dependent variables must be significant. It is satisfied as the significant relationship of CG and firm performance is shown in the literature (Coles et al., 2012; Francis et al., 2012; Adams et al., 2010; Renders et al., 2010; Belkhir 2009, Larmou and Vafeas 2009; Che-Haat et al., 2008).

ii) The link between independent and mediator variables must be significant. It is satisfied as the significant relationship of CG and IC is shown in the literature (Zamani et al., 2012; Abidin et al., 2009; Swartz and Firer 2005; Ho and Williams 2003).

iii) The link between dependent and mediator variables must be significant. It is satisfied as the significant relationship of IC and corporate performance is shown in the literature (Chen et al., 2005; Ze'ghal and Maaloul 2010; Chan 2009; Komnenic and Pokrajc ic 2012; Mehralian et al., 2012; Pal and Soriya 2012).

iv) If the direct link between CG and Corporate performance is reduced to zero after inclusion of IC i.e. mediator and indirect relationship becomes significant then it shows full mediation. If the direct link is significantly reduced then it shows partial mediation but if the direct link is still significant, there is no mediation.

However, Hayes (2013) argued that the causal chain given by Baron and Kenney (1986) is not appropriate and it is possible that mediation can exist in the absence of first condition. He further argued that the claim that independent variable cannot affect dependent variable indirectly in the absence of any relationship is false. According to Kraemer et al., (2008) temporal precedence is another important condition which has to be met in case of mediation analysis. It means independent variable must precede in time to mediator. This condition is satisfied as it is the responsibility of corporate governors to acquire and utilize IC resources properly in order to enhance corporate performance. The criteria to explain the likelihood of a variable to be a potential candidate of mediator is given in the following table.

Table 1: Criteria for a mediator

\begin{tabular}{|l|l|l|}
\hline Description & Baron and Kenny approach 1988 & MacArthur Approach (Kraemer et al.,2008) \\
\hline Link between IV and DV & Must be a strong link & Must be a link \\
\hline Link between IV and M & Must be a link & Must be a link \\
\hline Link between M and DV & Must be a link & Must be a link \\
\hline Temporal precedence & Desirable if IV before mediator (M) & IV must be before mediator (M) \\
\hline Analytical criteria & No interaction between IV and M & interaction between IV and M \\
\hline
\end{tabular}


This study suggests on the foundations of resource dependence theory that different board characteristics (IV) contribute to the intellectual capital (M) of the organization through their expertise, knowledge, experience, broad exposure, relational capital, and gender diversity and then intellectual capital lead to higher corporate performance (DV) eventually (Ho and Williams, 2003). Resource dependence theory of corporate governance states that it is the responsibility of board of directors to not only acquire, retain and utilize competent and skilled human resources from the labour market but also acquire the structural resources in terms of new and latest technology, production processes to produce quality and patent products and services and develop relations with the stakeholders of business like customers, suppliers, creditors and government agencies to get favor and develop competitive advantage. It is argued that board of directors is the part of human resource in the organization and non-executive directors contribute in terms of knowledge, vast experience and broad exposures due to working in different boards and also represent relational capital of the board. Financial qualification and tenure of directors also bring valuable understanding of business affairs due to their education and experience. Inside directors i.e. executive directors working on other boards also represent relational capital of the board and bring important information and resolve diversified issues in their board as they are handled in other boards. Females' directors contribute for their innovative, unique and strategic decision making role to increase IC performance. Overall, on the basis of methodological and theoretical reasoning given above, this study propose last hypothesis as:

H4: The relationship between $C G$ and corporate performance is significantly mediated by IC

\section{Theoretical Foundations and Conceptual Framework}

The relationship between board characteristics and corporate performance has been examined, mainly on the basis of agency theory and stakeholder theory, in the previous studies. Generally, agency theory looks management as a person of self-interest and conspirator whose actions and behaviour should be kept in check and under control. Stakeholder theory argues that shareholders are not the only stakeholders in the firm, but there are other groups like suppliers, customers, government and society which require board attention to protect their interests. It is the obligation of the firm to act as a socially responsible citizen (Maharaj, 2008). In both agency and stakeholder theories, board focuses on value protection rather value creation. It means that board tries to prevent any misappropriation of profit, which is already earned, from management or stakeholders.

Resource dependency theory and stewardship theory are used for the theoretical framework of this study. Resource dependency theory states that board is responsible for collecting valuable resources including physical, human, structural and relational capital from its environment. Board is thought to be networker with outside organizations to seek ways for the benefits of the organization. This viewpoint is generated through the concept of value creation to assist value increasing attitudes. In this perspective, board acts as a strategic resource and prime source of leadership (Voordeckers et al., 2007). Resource-based theory takes IC as a strategic resource in the same way as that of physical and financial capital which is responsible for achieving competitive advantage (Ze'ghal \& Maaloul 2010). The IC-based theory developed on the foundations of resource dependency theory ruminate IC as the only strategic resource to create value addition for a company (Reed et al., 2006). This is the reason that the theoretical foundation of almost every IC research is based on resource-based theory.

In stewardship theory, management is deemed as loyal and trustworthy and can be dependable to maximize earnings for shareholders (Donaldson, 1990). This means that monitoring is not required by external directors because executive directors understand the business well. External directors cannot compete with them in the area of firm specific knowledge and expertise. However, Research supports the idea that outside directors carry transferable skills and knowledge to be contributed in the best interest of the organization and act as valuable resources rather than auditors (Mueller et al., 2008). It means that outside directors may offer more advising and counseling role and less monitoring and controlling role in the organization.

Value creation is the key outcome from intellectual resources owned by the companies (Pulic 2004). It is the assumption of this study that human resources give their best when there is counselling and coordination between board and management. Value creation is achieved when resource dependency and stewardship theories are followed in the context of corporate governance and performance (Finkelstein et al., 2009). The second reason to have this theoretical perspective is increased complexity of political, economic, technological and social changes faced by firms. In this situation, board must be there to support managers by advising them, acting as discussion boards, providing managers access to the resources and also in touch with external links. All of these activities may help managers to add value (Finkelstein et al, 2009).

Corporate governance is responsible for developing competitive advantage for the company in today's free market economy. This is achievable if the board of directors cultivates value creation efficiency from the human brain's creativity 
$(\mathrm{HC})$, organizational structure (SC) and customer relations. The research framework of this study shown in Figure1 depicts the influence of CG measures on corporate performance through IC. IC acts as mediator and theoretically, the application of mediation is to "explain" why a relationship between exogenous construct i.e. CG measures and endogenous construct, i.e. corporate performance exists. The theoretical structural model of this study is shown in the following diagram, developed with the help of SmartPLS software (Ringle et al. 2005), which demonstrates the links between three important areas of the research world i.e. CG, IC and corporate performance.

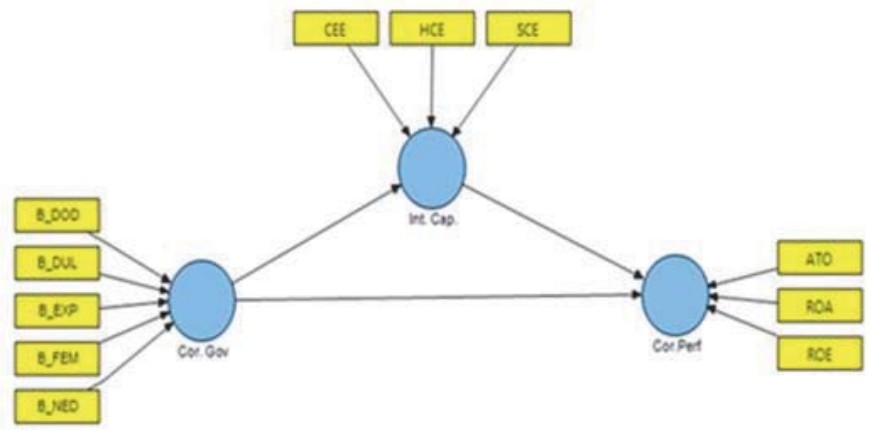

Figure 1: Conceptual framework of study.

[Cor.Gov= corporate governance and is represented by 5 characteristics of board of directors such as B_DOD= board directors having outside directorship, B_DUL= chairman of board is also the CEO of company, B_EXP= board directors have financial qualification and experience, B_FEM= female board of directors on board, B_NED= non-executive directors on board.

Int.Cap = Intellectual capital and is measured by human, structural and capital employed efficiency such as

$\mathrm{HCE}=$ human capital efficiency and measured by VA / HC Where VA = value added $\mathrm{HC}=$ human capital, which is calculated from total employee expenditure

SCE = structural capital efficiency and measured by SC/VA Where SC = structural capital VA = value added. And $\mathrm{SC}=\mathrm{VA}-\mathrm{HC}$,

$\mathrm{CEE}=$ capital employed efficiency and measured by VA/CE Where VA = value added $\mathrm{CE}=$ book value of capital employed efficiency

Cor.Perf= corporate performance and is measured by three traditional accounting measures such as

$\mathrm{ROA}=$ return on total assets and measured by operating profit/ total assets, ROE = return on equity and measured by net profit/common stock equity, ATO= assets turnover ratio and measured by net sales/total assets.]

\section{Research Methodology}

The research framework (Figure1) shows that this is quantitative research study which is the systematic empirical study of social phenomena through statistical, mathematical or computational methods (Given, 2008). In simple words, a quantitative researcher gathers a sample of numerical data and analyzes the data with the help of statistics. In this study, the data will be gathered from public listed companies in different stock exchanges through five main sources namely DataStream, respective stock exchanges; SE, respective securities and exchange commissions; SEC, the firms' annual reports and websites. Most of the variables discussed in study can be taken from SE, SEC and the firms' annual reports. The data which is not available in these reports may be collected from respective firms' websites. The study should be longitudinal in nature as the mediation cannot be consistent and confirmed just on the basis of one data set. In order to show consistency in mediation analysis and to substantiate that mediation continues to take place over number of years, it is recommended to use yearly data for eight to ten years' time period.

The conceptual model can be made more strong and robust if researchers use control variables along with independent and mediator variables. This study recommends using different control variables based upon the need and importance of that variable in the study. For instance, at the board level; the board size, board meetings, board remuneration and number of executives and at company level; the firm size, firm growth, industry type, leverage, etc. can 
be used as control variables to test the impact of these on the proposed model. In previous studies, the role of these variables as predictors of IC and corporate performance has been ascertained. For example, Wang et al. (2012) showed the negative impact of board size on firm performance when they tested the relationship in bank holding companies in USA. Shukeri et al. (2012) found positive link of size of boards with firm performance after having analyzed 300 publically listed companies in Malaysia. Vafeas (1999) declared that the more number of board meetings in a year leads to higher corporate performance in the next year. Makki and Lodhi (2009) confirmed the role of number of executives to enhance IC and corporate performance. Companies pay for the performance of directors which is determined by their capabilities, qualification, experience and knowledge and more pay may mean more expert and knowledgeable directors on board. In the same way, large firms have the ability to acquire more IC and other resources as compared to small size firms. Morariu, (2014) found high tech. industries require more IC intensive resources as compared to ordinary businesses which require more input and physical resources.

It is important to mention that this research framework, when tested empirically, must use Partial Least Square approach of structural equation modeling (PLS-SEM) for analysis of data. PLS is a non-parametric SEM method portrayed as "second generation multivariate analysis technique". It is, therefore, known as a soft modeling technique which does not oblige a normal distribution assumption (Chin, 2010; Hair, et al., 2014). Wolds (1975) clarifies that PLS is an influential and powerful technique of analysis because of its negligible demands on measurement scales, sample size and residual distribution. Keeping in view the gimmicks of PLS, for example, littler sample prerequisite, no supposition about multivariate normality, capacity to handle reflective and formative indicators and its vigor with less identification issues, it has been suggested for this study to be empirically tested.

PLS approach is also called Path model approach which is a diagram used to outwardly show the hypotheses and variable connections that are inspected when SEM is used (Hair et al., 2014). Constructs (directly not measureable) are symbolized as oval or circle in path diagram (Figure1). The indicators are directly measured proxy variables which hold the raw information. They are denoted as rectangles in path models (Figure1). Association between constructs as well as between construct and its allocated indicators are revealed as arrows. In PLS-SEM, the arrows are single headed so displaying predictive relationship and with solid theoretical background may be construed as causal relationship (Hair et al., 2014).

There are two models in PLS-SEM; measurement model and structural model. Both of them have to be evaluated differently. In measurement model the data is to be checked for validity, reliability, collinearity and statistical significance of outer weights or/and outer loadings of the indicators (Hair et al, 2014). While in structural model, it is to be checked for collinearity, the significance of the path coefficients, the level of the $\mathrm{R}^{2}$ values, the $\mathrm{f}^{2}$ effect size, and the predictive relevance i.e. Q² (Hair et al, 2014)

\section{Conclusion}

This study uses five CG measures which can contribute to the IC and then IC leads to corporate performance. Authors of this study believe that this is the first study to consider IC as mediator in any set of relationship. It is proposed that corporate governance measures and intellectual capital of firms yields higher corporate performance. Earlier, only the relational studies between these variables have been conducted separately. This study tries to build up a link between these variables by mediation.

This study underlines the need for Corporate Governance bodies to draw the rules for measuring and revealing IC in annual financial reports. If data identified with IC, safety and corporate social issues is unveiled in the yearly reports, it may increase the worth of companies in the eyes of investors. The study would be exceptionally advantageous for business managers to attract and exploit IC resources alongside physical assets. The study urges the corporate governors to assess the performance of Human, Structural and Capital employed resources to improve general business efficiency through redirecting limited resources in the value creation pattern.

This study also gives suggestion to the Securities and Exchange Commissions; SEC, institutes of corporate governance etc. to generate IC awareness programs for the board of directors of companies.

\section{References}

Abdullah, S. N., Ismail, K. N., \& Nachum, L. 2012. Women on boards of Malaysian firms: Impact on market and accounting performance. Available at SSRN: http://ssin.com/abstract=2145007

Abdullah, A., \& Page, M., 2009. Corporate governance and corporate performance: UK FTSE 350 Companies, Institute of Chartered Accountants of Scotland, Edinburgh, UK. 
Abidin, Z. Z., Kamal, N. M., \& Jusoff, K. (2009). Board Structure and Corporate Performance in Malaysia. International Journal of Economics And Finance, 1(1), 150-164.

Adams, R., \& Ferreira, D. (2009). Women in the board room and their impact on governance and performance. Journal of Financial Economics, 94, 291-309.

Adams, R. B., Hermalin, B. E., \& Weisbach, M. S. 2010. The role of boards of directors in corporate governance: A conceptual framework and survey. Journal of Economic Literature 48(1): 58-107.

Bai, C.-E., Liu, Q., Lua, J., Song, F. M., \& Zhang, J. 2004. Corporate governance and market valuation in China. Journal of Comparative Economics 32: 599-616.

Baron, R. M., \& Kenny, D. A. 1986. The Moderator-Mediator variable distinction in social psychological research: Conceptual, strategic, and statistical considerations. Journal of Personality and Social Psychology 51(6): 1173-1182.

Bebchuk, L. A., Cremers, M., \& Peyer, U. (2011). The CEO pay slice. Journal of Financial Economics, 102(1), 199-221.

Becker, B.E., Huselid, M.A. and Ulrich, D. (2001). The HR scorecard, Harvard Business School Press; M.A

Belkhir, M. 2009. Board of director's size and performance in banking. International Journal of Managerial Finance 5: 201-221.

Bilimoria, D. (2000). Building the business case for women corporate directors. In Women on Corporate Boards of Directors: International Challenges and Opportunities. Dordrecht, the Netherlands: Burke RJ, Mattes MC (eds). Kluwer Academic.

Bilimoria, D. (2006). The relationship between women corporate directors and women corporate officers. Journal of Managerial Issues, $18(1), 47-61$.

Bontis, N. (2004). National Intellectual Capital Index: A United Nations initiative for the Arab region. Journal of Intellectual Capital, 5(1), 13-39.

Brooking, A. (1997). The management of intellectual capital. Long Range Planning, 30.

Brown, D., Brown, D., \& Anastasopoulos, V. (2002). Women on boards: not just the right thing...but the 'bright' thing. The Conference Board of Canada, (pp. 341-02). Ottawa.

Cadbury Report, The. 1992. Report of the committee on the financial aspects of corporate governance. Gee Ltd (Professional Publishing Ltd): London.

Carcello, J. V., Hermanson, D. R., Neal, T. L., \& Jr, R. A. (2002). Board characteristics and audit fees. Contemporary Accounting Research, 19(3), 365-384.

Chan, K. 2009. Impact of intellectual capital on organizational performance: an empirical study of companies in the Hang Sang Index (part 1). The Learning Organization 16(1): 4-21.

Chhaochharia, V., \& Grinstein, Y. (2007). Corporate Governance and Firm Value: The Impact of the 2002 Governance Rules. Journal of Finance, 62(4), 1789-1825.

Che-Haat, M., Rahman, R., \& Mahenthiran, S. (2008). Corporate governance, transparency and performance of Malaysian companies. Managerial Auditing Journal, 23(8), 744-778.

Chen, M., Cheng, S., \& Hwang, Y. (2005). An empirical investigation of the Relationship between Intellectual Capital and Firm's Market Value and Financial Performance, Vol. (6) 2, 159-176. Journal of Intellectual Capital, 6(2), 159-176.

Chin, W. W., (2010) How to write and report PLS analysis? In: Handbook of partial least squares; concepts, methods and applications in marketing and related fields. Berlin: springer, pp. 655-690.

Coles, J. L., Daniel, N. D., \& Naveen, L. (2012). Board Advising. Available at SSRN: http://ssrn.com/abstract=2002250 or http://dx.doi. org/10.2139/ssrn.2002250.

Coles, J. W. 2001. An examination of the relationships of governance mechanisms to performance. Journal of Management and Governance 27(1): 23-50.

Cremers, K. J., \& Nair, V. B. (2005). Governance Mechanisms and Equity Prices. The Journal of Finance, 60(5), Vol. 60, No. 5, pp. 2859-2894.

Daily, C., Certo, S., \& Dalton, D. (1999). A decade of corporate women: some progress in the boardroom, none in the executive suite. Strategic Management Journal, 20, 93-99.

Dalziel, T., Gentry, R. J., \& Bowerman, M. 2011. An integrated agency-resource dependence view of the influence of directors' human and relational capital on firms' R\&D Spending. Journal of Management Studies 48(6): 1218-1242.

Dezs, C. L., \& Ross, D. G. 2012. Does female representation in top management improve firm performance? A panel data investigation. Strategic Management Journal 33: 1072-1089.

Dhaliwal, D., Naiker, V., \& Navissi, F. (2010). The Association between Accruals Quality and the Characteristics of Accounting Experts and Mix of Expertise on Audit Committees. Contemporary Accounting Research, 27(3), 782-827.

Donaldson, L. 1990. The ethereal hand: organizational economics and management theory. Academy of Management Review, $369-382$.

Donaldson, T., \& Preston, L. (1995). The stakeholder theory of the corporation: concepts, evidence and implication. Academy of Management Review, 20(1), 65-91.

Dzinkowski, R. (2000). The measurement and management of intellectual capital: an introduction. 78(2):32-36. Management Accounting, $78(2), 32-36$

Edvinson, L., \& Malone, M. 1997. Intellectual capital: realizing your company's true value by finding its hidden brainpower. New York: Harper Business.

Fama, E., \& Jensen, M. C. (1983). Separation of ownership and control. . Journal of Law and Economics, 26, 301-325.

Finkelstein, S., Ham brick, D. C., \& Canella, A. A. 2009. Strategic leadership; theory and research on executives, top management teams and boards. Oxford: Oxford university Press. 
Francis, B., Hasan, I., \& Wu, Q. (2012). Do corporate boards affect firm performance? New evidence from the financial crisis. Bank of Finland Research Discussion Papers.

Given, L. M. (2008). The Sage encyclopedia of qualitative research methods. Los Angeles, California: Sage Publications

Graves, L., \& Powell, G. (1988). An investigation of sex discrimination in recruiters' evaluations of actual applicants. Journal of Applied Psychology, 73(1), 20-29.

Goh, P. C. (2005). Intellectual capital performance of commercial banks in Malaysia. Journal of Intellectual Capital, 6(3), 386-395.

Gul, S., Sajid, M., Khan, M. B., Bukhari, S. A., \& Iqbal, J. 2011. The relationship between corporate governance and firm performance (Evidence from Textile Sector of Pakistan). Asian Journal of Business and Management Sciences 1(12): 45-53.

Gupta, K., Krishnamurti, C., \& Tourani-Rada, A. 2013. Is corporate governance relevant during the financial crisis? Journal of International Financial Markets, Institutions and Money: 85-110.

Hair, J., Hult, G., Ringle, C. and Sarstedt, M., (2014) A Primer on Partial Least Squares Structural Equation Modeling (PLS-SEM). Thousand Oaks: Sage Hayes, A. F. (2013). Introduction Mediation, Moderation and Conditional Process Analysis: A regression based approach, the Guilford, New York

Ho, C., \& Williams, S. M. 2003. International comparative analysis of the association between board structure and the efficiency of value added by a firm from its physical capital and intellectual capital resources. International Journal of Accounting 38: 465-491.

Ho, C.-L. (2011). Board Composition, Risk Management and corporate performance in the Taiwanese Life Insurance Industry. The IUP Journal of Risk and Insurance, 8(4), 7-27.

Keenan, J., \& Aggestam, M. (2001). Corporate governance and intellectual capital: some conceptualizations, Corporate Governance. An International Review, 9(4), 259-275.

Khan, A., \& Awan, D. S. 2012. Effect of board composition on firm's performance: a case of Pakistani listed companies. Interdisciplinary Journal of Contemporary Research in Business 3(10): 853-863.

Kim, K., Mauldin, E., \& Patro, S. (2011). Directors' Firm-Specific Knowledge versus Individual Expertise and Board Performance. corporate governance. Missouri: university of Missouri

Kini, O., Dass, N., Onal, B., Wang, J., \& Nanda, V. K. 2011. Board expertise: Do directors from related industries help bridge the information gap? 23rd Australasian Finance and Banking Conference 2010 Paper. Available at SSRN:http://ssrn.com/abstract= 1663584 or http://dx.doi.org/10.2139/ssrn.1663584

Komnenic, B., \& Pokrajc ${ }^{\circ i c}$ D. 2012. Intellectual capital and corporate performance of MNCs in Serbia. Journal of Intellectual Capital 13(1): 106-119.

Kraemer, H. C., Kiernan, M., \& Essex, M. (2008). How and Why Criteria Defining Moderators and Mediators Differ Between the Baron and Kenny and MacArthur Approaches. Health Psychology, 101-108.

Larmou, S., \& Vafeas, N. 2009. The relation between board size and firm performance in firms with a history of poor operating performance. Journal of Management Governance 14(1): 61-85.

Maditinos, D., Chatzoudes, D., Tsairidis, C., \& Theriou, G. 2011. The impact of intellectual capital on firms' market value and financial performance. Journal of Intellectual Capital 12(1): 132-151.

Maharaj, R. (2008). critiquing and contrasting "moral" stakeholder theory and "strategic" stakeholder: Implication for the board of directors. corporate governance, 115-127

Makki, M. M., \& Lodhi, S. A. 2009. Impact of intellectual capital on return on investment in Pakistani corporate sector. Australian Journal of Basic and Applied Sciences 3(3): 2995-3007.

Makki, M., Lodhi, S., \& Rahman, R. 2008. Intellectual capital performance of Pakistani listed corporate sector. International Journal of Business and Management 3(10): 45-51.

Masulis, R. W., \& Mobbs, S. 2011. Are all inside directors the same? Evidence from the external directorship market. The Journal of Finance LXIV (3): 823-872.

Mehralian, G., Rajabzadeh, A., Sadeh, M. R., \& Rasekh, H. R. (2012). Intellectual capital and corporate performance in Iranian pharmaceutical industry. Journal of Intellectual Capital, 13(1), 138-158.

Mention, A. L. 2012. Intellectual capital, innovation and performance: A systematic review of the literature. Business and Economic Research 2(1): 1-37.

Morariu, C. M. (2014). "Intellectual capital perfor mance in the case of Romanian public companies." Journal of Intellectual Capital 15(3): 392-410.Mueller, J., Ingley, C., \& cocks, G. (2008). the blender approach to governance leadership: Do diverse director attributes contribute to board capital. managing in the pacific century. Auckland: ANZAM.

Nicholson, G. J., Alexander, M., \& Kiel, G. C. 2004. Defining the social capital of the board of directors: an exploratory study. Journal of Australian New Zealand Academy of Management 10(1): 54-72.

OECD. 1999. Organization for Economic Co-operation and Development (OECD) (1999), Guidelines and instructions for OECD symposium. International Symposium Measuring Reporting Intellectual Capital: Experience, Issues, and Prospects, June. Amsterdam, OECD, Paris.

Pal, K., \& Soriya, S. (2012). IC performance of Indian pharmaceutical and textile industry. Journal of Intellectual Capital, 13(1), $120-137$.

Phusavat, K., \& Kanchana, R. (2007). Competitive priorities of manufacturing firms in Thailand. Industrial Management \& Data Systems, 107(7), 979-996.

Pulic, A. 2004. Intellectual capital- Does it create value or destroy it? Measuring Business Excellence 8(1): 62-68.

Rahman, S. 2012. The role of intellectual capital in determining differences between stock market and financial performance. International Research Journal of Finance and Economics: 46-77. 
Reed, K.K., Lubatkin, M. \& Srinivasan, N. (2006), "Proposing and testing an intellectual capital-based view of the firm", Journal of Management Studies, Vol. 43 No. 4, pp. 867-93.

Renders, A., Gaeremynck, A., \& Sercu, P. (2010). Corporate governance ratings and company performance: A Cross-European study. Corporate Governance: An International Review, 18(2), 87-106.

Riahi-Belkaoui, A. (2003). Intellectual capital and firm performance of US multinational firms: a study of the resource-based and stakeholder views. Journal of Intellectual Capital, 4(2), 215-226.

Ringle, C.M., Wende, S., and Will, A. "SmartPLS 2.0," www.smartpls.de, Hamburg, 2005. Retrieved from http://www.smartpls.com

Shleifer, A. \& R. Vishny. 1997. A survey of corporate governance. Journal of Finance 94(2): 737-783.

Shukeri, S. N., Shin, O. W., \& Shaari, M. S. 2012. Does board of director's characteristics affect firm performance? Evidence from Malaysian public listed companies. International Business Research 5(9): 120-127.

Skinner, D. (2008). Accounting for intangibles-a critical review of policy recommendations. Accounting and Business Research, 38(3), 191-204.

Skyrme, D. J. (1998). Valuing Knowledge: Is It Worth It? Managing Information, 8(3).

Solomon, J.F. 2007. Corporate governance and accountability. (2nd ed.). Wiley: New York.

Stewart, T. A. (1997). (1997) Intellectual capital: the new wealth of organizations. London: Nicholas Brealey.

Sullivan, P. (2000). Value driven intellectual capital: how to convert intangible corporate assets into market value. New York: John Wiley $\&$ Sons Inc.

Swartz, N.-P., \& Firer, S. 2005. Board structure and intellectual capital performance in South Africa. Meditari Accountancy Research 13(2): 145-166.

Topak, M. S. 2011. The effect of board size on firm performance: Evidence from turkey. Middle Eastern Finance and Economics 14: 119127.

Vafeas, N., (1999). Board meeting frequency and firm performance, Journal of fianancial economics, 53: 113-142

Voordeckers, W., Gills, A. V., \& Heuvel, J. V. 2007. Board composition in small and medium sized family firms. Journal of Small Business Management: 137-156.

Wang, W.-K., Lu, W.-M., \& Lin, Y.-L. (2012). Does corporate governance play an important role in BHC performance? Evidence from the U.S. Economic Modelling, 29, 751-760.

Weir, C., McKnight, P., \& Laing, D. (2002) Internal and external governance mechanisms: Their impact on the performance of large UK public companies. Journal of Business Finance and Accounting, 29(5-6), 579-611.

Williams, R. (2003) Women on corporate boards of directors and their influence on corporate philanthropy. Journal of Business Ethics, 42(1), 1-10.

Williams, S. M. 2000. Relationship between board structure and a firm's intellectual capital performance in an emerging economy. Working Paper, University of Calgary, Canada.

Wolds, H., (1975). Path models with latent variables; the NIPALS approach. In: Quantitative sociology: international perspective on mathematical and statistical modeling. New York: academic press, pp. 307-357.

Zahn, J.-L. W., Neilson, J., \& Tower, G. (2004). Intellectual Capital and the Efficiency of Value Added: Trends in the Singapore Capital Market 2000-2002. Australia: Burleigh M.D.C., Old Poseidon Books.

Zamani, F. G., Nahandi, Y. B., Lalepour, M., \& Re-zagholibeyghi, A. 2012. The relation between corporate governance and intellectual capital stressing human capital characteristics. International Journal of Business and Management Tomorrow 2(7): 1-7.

Ze'ghal, D., \& Maaloul, A. 2010. Analyzing value added as an indicator of intellectual capital and its consequences on company performance. Journal of Intellectual Capital 11(1): 39-60. 